The $1^{\text {st }}$ Conf. of SSFOP "Future of Ornamental Plants in Egypt", Cairo, Egypt, 22/2/2015

Scientific J. Flowers \& Ornamental Plants

www.ssfop.com/journal

ISSN: 2356-7864

\title{
RESPONSE OF PEPEROMIA OBTUSIFOLIA (L.) A. DIETR CV. VARIEGATA PLANT TO SOME FERTILIZATION TREATMENTS
}

\author{
Boshra A. El-Sayed"; S.M. Shahin ${ }^{* *}$ and Azza M. Abdel-Moniem \\ * Ornamental Plants and Landscape Gardening Res. Dept., Hort. Res. Inst., ARC, Giza, Egypt. \\ ** Botanical Gardens Res. Dept., Hort. Res. Inst., ARC, Giza, Egypt.
}

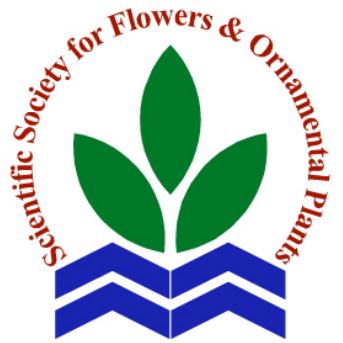

Scientific J. Flowers \& Ornamental Plants, 2(1):127-134 (2015).

Received:

$18 / 12 / 2014$

Revised by:

Prof. Dr. Eman M. Abou El-Ghait, Banha Univ.

Prof. Dr. M.M. Farahat, Agric. \& Biol. Res. Div., NRC.

ABSTRACT: An experiment was established under plastic house at the nursery of Hort. Res. Inst., ARC, Giza, Egypt during 2012 and 2013 seasons to find out the effect of foliar spraying with active dry yeast solution at $0,1,3$ and $5 \mathrm{~g} / \mathrm{l}$, soil drenching with NPK mixture (2:2:1) at $2 \mathrm{~g} /$ pot and the interaction between each level of yeast and that of NPK mixture on growth and chemical composition of 3months-old transplants of Peperomia obtusifolia (L.) A. Diter. grown in 14-cm-diameter plastic pots filled with about $1 \mathrm{~kg}$ of an equal mixture of washed sand, clay and peatmoss (1:1:1, by volume.)

The obtained results indicated that various single and combined treatments improved all vegetative and root growth parameters with various significant differences compared to the control in both seasons. Active dry yeast alone at $3 \mathrm{~g} / \mathrm{l}$ treatment gave better result than the other individual ones, whereas comparing between any level of dry yeast combined with NPK ( $2 \mathrm{~g} / \mathrm{pot})$ was more effective in improving vegetative and root growth of plants than all the individual treatments, the interaction between $3 \mathrm{~g} / \mathrm{l}$ active dry yeast and $2 \mathrm{~g} /$ pot NPK recorded the best growth at all in both seasons. On the same line were those results of pigments content in the leaves reached maximum by 3 $\mathrm{g} / \mathrm{l}$ dry yeast, but the opposite was right regarding the percentages of total soluble sugars, $\mathrm{N}, \mathrm{P}$ and $\mathrm{K}$ content those reached the highest values by the level of $5 \mathrm{~g} / \mathrm{l}$ dry yeast in most cases of both seasons. However, content of those constituents was doubled by connecting between active dry yeast at any level and NPK mixture $2 \mathrm{~g} /$ pot, with the prevalence of $3 \mathrm{~g} / 1$ active dry yeast plus $2 \mathrm{~g} /$ pot NPK combination, that gave the highest content in the two seasons.

Hence, it can be recommended to fertilize Peperomia obtusifolia cv. Variegata plants cultivated in 14-cm-diameter plastic pots with active dry yeast at $3 \mathrm{~g} / 1$ (as a foliar spray) plus NPK mixture (2:2:1) at $2 \mathrm{~g} /$ pot (as a soil drench), 5 times with one month interval to obtain the best vegetative growth and high pot plant quality.

Key words: Radiator plant, Peperomia obtusifolia (L.) A. Dietr, NPK mixture, active dry yeast, fertilization treatments.

\section{INTRODUCTION}

Peperomia obtusifolia (L.) A. Diter., Radiatar plant (Fam. Piperaceae) is a popular ornamental foliage plant native to tropical America and southern Florida. It may be grown in pots, pans or hanging baskets for its attractive foliage (cv. Veriegata has variegated leaves make it more attractive). It is grow either in the ground as a low creeping groundcover or climbing on another plant (Bailey, 1976). Peperomia plants are compact, small succulent and herbaceous. Both stems and leaves are thick and fleshy with a smooth waxy surface. They tolerate low light density well and are easy to grow, which make them excellent house pot-plants (Huxley et al., 1992). 
Fertilization is still one of the most important methods essential for improving growth and quality of various plant species, especially pot-ones, which usually grow inside a limited space not exceed 3/4 of pot size and under go bad aeration plus the low illumination which may reduce or slow photosynthesis process in the leaves and consequently depress the food formation. So, fertilization under these stresses is obligatory. This was emphasized by ElSayed et al. (2007) whom demonstrated that nitrobien biofertilizer at $5 \mathrm{~g} /$ pot greatly improved vegetative and root growth of Peperomia obtusifolia cv. Veriegata plant and the leaf content of pigments, total carbohydrates, N, P and K. On Spathiphyllum wallisii, El-Sayed et al. (2010) reported that a combination of NPK mixture at $2 \mathrm{~g} /$ pot $+4 \mathrm{~g}$ active dry yeast caused a marked increment in plant height, No. leaves/plant, leaf area, root length, No. roots/plant and fresh and dry weights of leaves and roots, besides the leaf content of chlorophyll a, b, carotenoids and reduced sugars. Likewise, Samet et al. (2012) revealed that $250 \mu \mathrm{M}$ of yeast extract improved growth of Atropa belladonna and increased root content of scopolamine and hyoscyamine by 1.9 and 1.6 fold compared to control.

Like observations were also declared by Ali (2001) on Calendula officinalis, Ahmed (2002) on Lucaena leucocephala, Desouky
(2004) on Strelitzia reginae, Abdel-Wahed et al. (2006) on Euonymus japonicus, AbdelWahed (2007) on Brassaia arboricola and Abdel-Fattah et al. (2009) who found that foliar spray with active dry yeast at $8 \mathrm{~g} / 1$ improved growth and chemical composition of Brassaia actinophylla plant. However, this work was set out in order to investigate the response of Peperomia plant to foliar spray with active dry yeast, alone or combined with NPK fertilizer.

\section{MATERIALS AND METHODS}

A pot experiment was undertaken under plastic house at the nursery of Hort. Res. Inst., ARC, Giza, Egypt through the two successive seasons of 2012 and 2013 to determine the most effective fertilization treatment reliable for good growth and high quality of Peperomia foliage-pot-plant.

Therefore, homogenous 3-months-old transplants of Peperomia obtusifolia (L.) A. Diter. (10-12 cm long, carry about 4-5 leaves) were planted on April, $1^{\text {st }}$ for each season in 14-cm-diameter plastic pots (one transplant/pot) filled with about $1 \mathrm{~kg}$ of washed sand + clay + peatmoss mixture at equal parts by volume $(1: 1: 1, \mathrm{v} / \mathrm{v} / \mathrm{v})$, the physical and chemical analysis of the sand and clay used in the two seasons are shown in Table (1), while those of the used peat are illustrated in Table (2).

Table 1. Some physical and chemical properties of the used sand and clay in both seasons.

\begin{tabular}{|c|c|c|c|c|c|c|c|c|c|c|c|c|c|c|}
\hline \multirow[b]{2}{*}{ Soil type } & \multicolumn{4}{|c|}{ Particle size distribution (\%) } & \multirow[b]{2}{*}{ S.P. } & \multirow{2}{*}{$\begin{array}{c}\text { E.C. } \\
(\mathrm{dS} / \mathrm{m})\end{array}$} & \multirow[b]{2}{*}{ pH } & \multicolumn{4}{|c|}{ Cations (meq/l) } & \multicolumn{3}{|c|}{ Anions (meq/l) } \\
\hline & $\begin{array}{c}\text { Coarse } \\
\text { sand }\end{array}$ & $\begin{array}{l}\text { Fine } \\
\text { sand }\end{array}$ & Silt & Clay & & & & $\mathrm{Ca}^{++}$ & $\mathbf{M g}^{++}$ & $\mathrm{Na}^{+}$ & $\mathbf{K}^{+}$ & $\mathrm{HCO}_{3}^{-}$ & $\mathrm{Cl}^{-}$ & $\mathrm{SO}_{4}^{--}$ \\
\hline & 18.72 & 71.28 & & & & & 8.2 & 2.6 & 2.48 & 21.8 & & 3.85 & 13.00 & 10. \\
\hline Clay & 7.46 & 16.75 & 34.53 & 40.89 & 41.67 & 2.18 & 8.33 & 16.93 & 9.33 & 20.44 & 0.37 & 3.82 & 1.46 & 41.79 \\
\hline
\end{tabular}

Table 2. Some physical and chemical properties of the used peatmoss in both seasons.

\begin{tabular}{cccccc}
\hline Organic matter & $90-95 \%$ & Water relation capacity & $60-75 \%$ & $\mathbf{K}$ & $1.77 \%$ \\
Ash & $5-10 \%$ & Salinity & $0.3 \mathrm{~g} / 1$ & $\mathbf{F e}$ & $421 \mathrm{ppm}$ \\
Density (vol. dry) & $80-90 \mathrm{mg} / 1$ & $\mathbf{N}$ & $1.09 \%$ & $\mathbf{M n}$ & $72 \mathrm{ppm}$ \\
pH value & 3.4 & $\mathbf{P}$ & $0.23 \%$ & $\mathbf{Z n}$ & $41 \mathrm{ppm}$ \\
\hline
\end{tabular}


The transplants were properly reared till May, $1^{\text {st }}$, as they were received the following treatments:

1- No. fertilization, referred to as control.

2- Chemical fertilization, with NPK mixture $(2: 2: 1)$ at $2 \mathrm{~g} / \mathrm{pot}$, added as a soil drench, 5 times with one month interval. Ammonium sulphate $(20.5 \% \mathrm{~N})$, Casuperphosphate $\left(\begin{array}{lll}15.5 \% & \left.\mathrm{P}_{2} \mathrm{O}_{5}\right) & \text { and } \mathrm{K} \text { - }\end{array}\right.$ sulphate $\left(48.5 \% \quad \mathrm{~K}_{2} \mathrm{O}\right)$ fertilizers were used to obtain the required ratio.

3- Biofertilization with an aqueous solution of active dry yeast at the rates of 1,3 and $5 \mathrm{~g} / \mathrm{l}$ fortified with $30 \mathrm{~g}$ sucrose/l were applied as a foliar spray, 5 times with one month interval till the solution was run-off. The chemical composition of the active dry yeast used in both seasons is averaged in Table (3).

4- Each level of yeast was combined with NPK mixture (2 g/pot to form 3 combinations as follows:

a- Active dry yeast at $1 \mathrm{~g} / 1+2 \mathrm{~g}$ NPK mixture/pot.

b- Active dry yeast at $3 \mathrm{~g} / 1+2 \mathrm{~g}$ NPK mixture/pot.

c- Active dry yeast at $5 \mathrm{~g} / 1+2 \mathrm{~g} \mathrm{NPK}$ mixture/pot.

The layout of the experiment in the two seasons was a complete randomized design replicated thrice, as each replicate contained 5 plants (Mead et al., 1993). The regular agricultural practices recommended for this plantation were done whenever needed. The temperatures, relative humidity and light intensity inside the plastic house during the course of this study between: 25$39{ }^{\circ} \mathrm{C}, \quad 45-82 \%$ and 500-600 lux, respectively.

At the end of each seasons (on October, $1^{\text {st }}$ ) the following data were recorded: plant length $(\mathrm{cm})$, stem diameter $(\mathrm{cm})$, number of leaves/plant $(\mathrm{cm})$ as well as vegetative and root growth fresh and dry weights $(\mathrm{g})$. In fresh leaf samples taken from the middle parts of the plants, photosynthetic pigments (chlorophyll a, b and carotenoids, $\mathrm{mg} / \mathrm{g}$ f.w.) were measured according to the method of Saric et al. (1967), while in dry leaf ones, content of total soluble sugars (Dubois et al., 1956), nitrogen (Pregl, 1945), phosphorus (Cottenie et al., 1982) and potassium (Jackson, 1973) were evaluated as percentages.

Data were then tabulated and statistically analyzed according to program SAS Institute Program (1994), using Duncan's Multiple Range Test (Duncan, 1955), to compare among means of various treatments.

Table 3. Chemical composition of the active dry yeast used in the two seasons.

\begin{tabular}{|c|c|c|c|}
\hline Proteins & $47.00 \%$ & Niacin & $300-500 \mu / g$ \\
\hline Carbohydrates & $33.00 \%$ & Pyrodoxin & $28.0 \mu / \mathrm{g}$ \\
\hline Minerals & $8.00 \%$ & Pantathenate & $70.0 \mu / \mathrm{g}$ \\
\hline Nucleic acids & $8.00 \%$ & Biotin & $1.3 \mu / \mathrm{g}$ \\
\hline Lipids & $4.00 \%$ & Cholin & $4000 \mu / g$ \\
\hline Thiamine & $60.100 \mu / g$ & Folic acid & $5.13 \mu / \mathrm{g}$ \\
\hline Riboflavin & $33-50 \mu / g$ & Vitamin B12 & $0.001 \mu / \mathrm{g}$ \\
\hline \multicolumn{4}{|c|}{ Approximate composition of minerals (mg/g): } \\
\hline $\mathrm{Na}$ & 0.12 & $\mathbf{C u}$ & 8.00 \\
\hline $\mathbf{C a}$ & 0.75 & $\mathrm{Se}$ & 0.10 \\
\hline Fe & 0.02 & Mn & 0.02 \\
\hline Mg & 1.65 & $\mathrm{Cr}$ & 2.20 \\
\hline K & 21.00 & $\mathbf{N i}$ & 3.00 \\
\hline $\mathbf{P}$ & 13.50 & Va & 0.04 \\
\hline $\mathbf{S}$ & 3.90 & Мo & 0.40 \\
\hline $\mathbf{Z n}$ & 0.17 & Sn & 3.00 \\
\hline Si & 0.03 & $\mathbf{L i}$ & 0.17 \\
\hline
\end{tabular}




\section{RESULTS AND DISCUSSION}

\section{Effect of fertilization treatments on:}

\section{1- Vegetative and root growth traits:}

As shown in Tables (4 and 5), it is clear that means of all vegetative and root growth parameters were obviously increased in response to the different fertilization treatments employed in this study with various significant levels when compared to control means in both seasons. Among the individual treatments, active dry yeast at 3 $\mathrm{g} / \mathrm{l}$ was the best and followed by the same biofertilizer at higher concentration $(5 \mathrm{~g} / \mathrm{l})$. this may be attributed to the role of yeast in providing the plants with proteins, amino acids, minerals, ash, glycogen, fats, cellulose and vit. B (Table, 3). Moreover, yeast extract not only increases auxins and cytokinins, but also decreases abscisic acid (Abou El-Yazied and Mahdy, 2012). In this regard, Abdo et al. (2012) proved that application of yeast extract under stress of pollution with cadmium minimized the harmful effect of such heavy metal on ABA concentration and on $\mathrm{Cd}$ accumulation in leaves of soybean plants. Besides, Nassar et al. (2011) ascribed increasing stem diameter of Phaseolus vulgaris plants by 50,100 or $150 \mathrm{ml}$ active yeast extract/1 mainly to increase in thickness of epidermis, cortex, phloem tissue, xylem tissue and parenchymatous area of the pith more than those of the control. Such treatment also increased thickness of both midvein and lamina of leaflet blades, which was accompanied with increments in thickness of palisade and spongy tissues.

An extra improvement in vegetative and root growth of fertilized plants was noticed when combining between any level of active dry yeast and NPK mixture at $2 \mathrm{~g} /$ pot, especially the combining between $3 \mathrm{~g} / \mathrm{l}$ active dry yeast $+2 \mathrm{~g} /$ pot NPK that gave the tallest plants, thickest stems, highest No. leaves/plant, biggest leaf area and heaviest fresh and dry weights of vegetative and root growth at all in the two seasons. This may be due to lumping the beneficial effects of both yeast and NPK mixture in providing the plants with their requirements excessively. These results are in accordance with those detected by El-Sayed et al. (2007) on Peperomia obtusifolia cv. Variegata, Ali (2001) on Calendula officinalis, Desouki (2004) on Strelitzia reginae, Abdel-Wahed et al. (2006) on Euonymus japonicus, AbdelFattah et al. (2009) on Brassaia actinophylla and Samet et al. (2012) on Atropa belladonna.

\section{2- Chemical composition:}

A similar response to that of vegetative and root growth parameters was also occurred as well in respect of chlorophyll a, b and carotenoids content (mg/g f.w.), as the means of these pigments (Table, 6) were significantly increased in response to the different sole treatments in most cases of both seasons with the superiority of active dry yeast at $3 \mathrm{~g} / \mathrm{l}$ treatment that recorded the utmost high content at all. The opposite was the right concerning the percentages of total soluble sugars, N, P and $\mathrm{K}$ (Table, 7), which reached the maximum values by foliar application of active dry yeast at $5 \mathrm{~g} / 1$ relative to the other separate treatments with few exceptions in both seasons. This may be due to the role of active dry yeast in providing the plants with minerals, amino acids, carbohydrates, protein, fat, ash glycogen and other bioactive constituents, as shown before in Table (3). In this regard, Abou ElYazied and Mahdy (2012) mentioned that foliar spraying with yeast extract at $5 \mathrm{ml} / 1$ increased photosynthetic pigments, $\mathrm{N}, \mathrm{P}, \mathrm{K}$, $\mathrm{B}$, total sugars, total free amino acids and crude protein content in the leaves of Vicia faba plants. Likewise, Abdo et al. (2012) postulated that yeast extract at $60 \mathrm{ml} / 1$ improved the contents of photosynthetic pigments, total sugars, IAA and $\mathrm{GA}_{3}$ in the leaves cadmium-polluted soybean plants.

On the other hand combining between drenching the soil mixture with $2 \mathrm{~g} /$ pot of NPK and spraying the foliage with active yeast (at any level) induced more increment in the content of all the abovenamed constituents, but the excellence was also resulted from 
Table 4. Effect of fertilization treatments on vegetative growth of Peperomia obtusifolia (L.) A. Dietr cv. Veriegata plant during 2012 and 2013 seasons.

\begin{tabular}{lcccccccc}
\hline \multicolumn{1}{c}{ Treatments } & \multicolumn{2}{c}{ Plant length (cm) } & \multicolumn{2}{c}{ Stem diameter (cm) } & \multicolumn{2}{c}{ No. leaves/plant } & \multicolumn{2}{c}{ Leaf area $\left.\mathbf{( c m}^{\mathbf{2}}\right)$} \\
& $\mathbf{2 0 1 2}$ & $\mathbf{2 0 1 3}$ & $\mathbf{2 0 1 2}$ & $\mathbf{2 0 1 3}$ & $\mathbf{2 0 1 2}$ & $\mathbf{2 0 1 3}$ & $\mathbf{2 0 1 2}$ & $\mathbf{2 0 1 3}$ \\
\hline Control & $19.73 \mathrm{e}$ & $18.25 \mathrm{~d}$ & $0.43 \mathrm{c}$ & $0.39 \mathrm{c}$ & $7.72 \mathrm{~d}$ & $7.02 \mathrm{e}$ & $20.12 \mathrm{~d}$ & $25.34 \mathrm{~d}$ \\
NPK at 2 g/pot (A) & $23.98 \mathrm{de}$ & $23.00 \mathrm{~cd}$ & $0.48 \mathrm{c}$ & $0.42 \mathrm{c}$ & $9.76 \mathrm{~cd}$ & $9.21 \mathrm{de}$ & $21.73 \mathrm{~cd}$ & $26.22 \mathrm{~cd}$ \\
Yeast at 1 g/pot (B) & $22.52 \mathrm{e}$ & $22.13 \mathrm{~d}$ & $0.45 \mathrm{c}$ & $0.41 \mathrm{c}$ & $8.23 \mathrm{~d}$ & $8.00 \mathrm{e}$ & $20.54 \mathrm{~cd}$ & $26.00 \mathrm{~cd}$ \\
Yeast at 3 g/pot (C) & $31.89 \mathrm{c}$ & $29.24 \mathrm{~b}$ & $0.61 \mathrm{~b}$ & $0.55 \mathrm{~b}$ & $12.21 \mathrm{~b}$ & $11.99 \mathrm{~cd}$ & $23.71 \mathrm{bc}$ & $27.97 \mathrm{bc}$ \\
Yeast at 5 g/pot (D) & $24.72 \mathrm{~d}$ & $25.31 \mathrm{c}$ & $0.55 \mathrm{~b}$ & $0.49 \mathrm{bc}$ & $10.56 \mathrm{c}$ & $11.00 \mathrm{~d}$ & $22.00 \mathrm{c}$ & $26.99 \mathrm{c}$ \\
A+ B & $27.83 \mathrm{~cd}$ & $29.99 \mathrm{~b}$ & $0.62 \mathrm{~b}$ & $0.57 \mathrm{~b}$ & $11.38 \mathrm{bc}$ & $12.76 \mathrm{c}$ & $24.10 \mathrm{~b}$ & $28.31 \mathrm{bc}$ \\
A + C & $40.99 \mathrm{a}$ & $35.76 \mathrm{a}$ & $0.90 \mathrm{a}$ & $0.81 \mathrm{a}$ & $15.20 \mathrm{a}$ & $19.23 \mathrm{a}$ & $28.33 \mathrm{a}$ & $31.72 \mathrm{a}$ \\
A+ D & $36.28 \mathrm{~b}$ & $30.31 \mathrm{~b}$ & $0.82 \mathrm{ab}$ & $0.76 \mathrm{ab}$ & $13.82 \mathrm{ab}$ & $15.87 \mathrm{~b}$ & $25.60 \mathrm{ab}$ & $29.03 \mathrm{~b}$ \\
\hline
\end{tabular}

- Means within a column having the same letters are not significantly different according to Duncan's Multiple Range Test (DMRT) at 5\% level.

Table 5. Effect of fertilization treatments on vegetative growth and roots fresh and dry weights of Peperomia obtusifolia (L.) A. Dietr cv. Veriegata plant during 2012 and 2013 seasons.

\begin{tabular}{lcccccccc}
\hline \multirow{2}{*}{ Treatments } & \multicolumn{3}{c}{ Fresh weight (g) } & \multicolumn{3}{c}{ Fresh weight (g) } \\
& \multicolumn{2}{c}{ Vegetative growth } & \multicolumn{2}{c}{ Roots } & \multicolumn{2}{c}{ Vegetative growth } & Roots \\
& $\mathbf{2 0 1 2}$ & $\mathbf{2 0 1 3}$ & $\mathbf{2 0 1 2}$ & $\mathbf{2 0 1 3}$ & $\mathbf{2 0 1 2}$ & $\mathbf{2 0 1 3}$ & $\mathbf{2 0 1 2}$ & $\mathbf{2 0 1 3}$ \\
\hline Control & $18.95 \mathrm{~d}$ & $20.00 \mathrm{~d}$ & $5.99 \mathrm{e}$ & $5.96 \mathrm{e}$ & $3.29 \mathrm{e}$ & $3.00 \mathrm{e}$ & $2.00 \mathrm{~d}$ & $1.87 \mathrm{c}$ \\
NPK at 2 g/pot (A) & $20.22 \mathrm{~cd}$ & $21.99 \mathrm{c}$ & $7.96 \mathrm{de}$ & $6.90 \mathrm{de}$ & $4.81 \mathrm{~d}$ & $4.79 \mathrm{~d}$ & $2.70 \mathrm{bc}$ & $2.00 \mathrm{c}$ \\
Yeast at 1 g/pot (B) & $19.98 \mathrm{~d}$ & $20.87 \mathrm{~cd}$ & $6.82 \mathrm{e}$ & $7.34 \mathrm{~d}$ & $5.21 \mathrm{~cd}$ & $5.09 \mathrm{~cd}$ & $2.56 \mathrm{c}$ & $2.21 \mathrm{bc}$ \\
Yeast at 3 g/pot (C) & $21.34 \mathrm{c}$ & $23.21 \mathrm{bc}$ & $8.34 \mathrm{~d}$ & $9.21 \mathrm{c}$ & $5.99 \mathrm{c}$ & $5.89 \mathrm{c}$ & $2.77 \mathrm{bc}$ & $2.95 \mathrm{~b}$ \\
Yeast at 5 g/pot (D) & $24.96 \mathrm{bc}$ & $25.00 \mathrm{~b}$ & $9.88 \mathrm{~cd}$ & $9.99 \mathrm{bc}$ & $7.22 \mathrm{bc}$ & $6.80 \mathrm{bc}$ & $3.03 \mathrm{~b}$ & $2.99 \mathrm{~b}$ \\
A + B & $26.34 \mathrm{~b}$ & $28.24 \mathrm{ab}$ & $11.22 \mathrm{c}$ & $10.98 \mathrm{~b}$ & $7.98 \mathrm{~b}$ & $7.10 \mathrm{~b}$ & $3.42 \mathrm{ab}$ & $3.60 \mathrm{ab}$ \\
$\mathbf{A}+\mathbf{C}$ & $30.21 \mathrm{a}$ & $31.05 \mathrm{a}$ & $15.42 \mathrm{a}$ & $12.96 \mathrm{a}$ & $9.26 \mathrm{a}$ & $9.03 \mathrm{a}$ & $3.99 \mathrm{a}$ & $3.87 \mathrm{a}$ \\
$\mathbf{A}+\mathbf{D}$ & $27.99 \mathrm{ab}$ & $29.33 \mathrm{ab}$ & $13.21 \mathrm{~b}$ & $11.28 \mathrm{ab}$ & $8.00 \mathrm{~b}$ & $7.98 \mathrm{ab}$ & $3.52 \mathrm{ab}$ & $3.23 \mathrm{ab}$ \\
\hline
\end{tabular}

- Means within a column having the same letters are not significantly different according to Duncan's Multiple

Range Test (DMRT) at 5\% level.

Table 6. Effect of fertilization treatments on pigments content in the leaves of Peperomia obtusifolia (L.) A. Dietr cv. Veriegata plant during 2012 and 2013 seasons.

\begin{tabular}{lcccccc}
\hline \multirow{2}{*}{ Treatments } & \multicolumn{2}{c}{$\begin{array}{c}\text { Chlorophyll (a) } \\
\text { (mg/100 g f.w.) }\end{array}$} & \multicolumn{2}{c}{$\begin{array}{c}\text { Chlorophyll (b) } \\
\text { (mg/100 g f.w.) }\end{array}$} & \multicolumn{2}{c}{$\begin{array}{c}\text { Carotenoids } \\
\text { (mg/100 g f.w.) } \\
\end{array}$} \\
& $\mathbf{2 0 1 2}$ & $\mathbf{2 0 1 3}$ & $\mathbf{2 0 1 2}$ & $\mathbf{2 0 1 3}$ & $\mathbf{2 0 1 2}$ & $\mathbf{2 0 1 3}$ \\
\hline Control & $0.121 \mathrm{~d}$ & $0.200 \mathrm{~d}$ & $0.088 \mathrm{~d}$ & $0.099 \mathrm{c}$ & $0.110 \mathrm{~d}$ & $0.139 \mathrm{c}$ \\
NPK at 2 g/pot (A) & $0.150 \mathrm{c}$ & $0.226 \mathrm{~d}$ & $0.121 \mathrm{c}$ & $0.113 \mathrm{c}$ & $0.172 \mathrm{~b}$ & $0.158 \mathrm{bc}$ \\
Yeast at 1 g/pot (B) & $0.141 \mathrm{c}$ & $0.211 \mathrm{~d}$ & $0.110 \mathrm{~cd}$ & $0.102 \mathrm{c}$ & $0.152 \mathrm{c}$ & $0.163 \mathrm{bc}$ \\
Yeast at 3 g/pot (C) & $0.163 \mathrm{c}$ & $0.298 \mathrm{bc}$ & $0.130 \mathrm{c}$ & $0.126 \mathrm{c}$ & $0.181 \mathrm{~b}$ & $0.171 \mathrm{~b}$ \\
Yeast at 5 g/pot (D) & $0.159 \mathrm{c}$ & $0.240 \mathrm{~d}$ & $0.122 \mathrm{c}$ & $0.122 \mathrm{c}$ & $0.162 \mathrm{c}$ & $0.169 \mathrm{~b}$ \\
A + B & $0.169 \mathrm{c}$ & $0.251 \mathrm{c}$ & $0.187 \mathrm{~b}$ & $0.196 \mathrm{~b}$ & $0.171 \mathrm{~b}$ & $0.176 \mathrm{~b}$ \\
A + C & $0.321 \mathrm{a}$ & $0.385 \mathrm{a}$ & $0.210 \mathrm{a}$ & $0.248 \mathrm{a}$ & $0.240 \mathrm{a}$ & $0.251 \mathrm{a}$ \\
A + D & $0.270 \mathrm{~b}$ & $0.316 \mathrm{~b}$ & $0.193 \mathrm{a}$ & $0.230 \mathrm{a}$ & $0.221 \mathrm{a}$ & $0.217 \mathrm{ab}$ \\
\hline
\end{tabular}

- Means within a column having the same letters are not significantly different according to Duncan's Multiple Range Test (DMRT) at $5 \%$ level. 
Boshra A. El-Sayed et al.

Table 7. Effect of fertilization treatments on total soluble sugars, $N, P$ and $K$ content in the leaves of Peperomia obtusifolia (L.) A. Dietr cv. Veriegata plant during 2012 and 2013 seasons.

\begin{tabular}{lcccccccc}
\hline \multicolumn{1}{c}{ Treatments } & \multicolumn{2}{c}{ Total soluble sugars } & \multicolumn{2}{c}{ N (\%) } & \multicolumn{2}{c}{ P (\%) } & \multicolumn{2}{c}{ K (\%) } \\
& $\mathbf{2 0 1 2}$ & $\mathbf{2 0 1 3}$ & $\mathbf{2 0 1 2}$ & $\mathbf{2 0 1 3}$ & $\mathbf{2 0 1 2}$ & $\mathbf{2 0 1 3}$ & $\mathbf{2 0 1 2}$ & $\mathbf{2 0 1 3}$ \\
\hline Control & $10.73 \mathrm{~d}$ & $12.71 \mathrm{e}$ & $1.07 \mathrm{c}$ & $1.20 \mathrm{c}$ & $0.10 \mathrm{c}$ & $0.14 \mathrm{c}$ & $0.99 \mathrm{c}$ & $1.06 \mathrm{c}$ \\
NPK at 2 g/pot (A) & $14.60 \mathrm{ab}$ & $15.43 \mathrm{c}$ & $1.28 \mathrm{bc}$ & $1.31 \mathrm{bc}$ & $0.21 \mathrm{~b}$ & $0.23 \mathrm{~b}$ & $1.18 \mathrm{~b}$ & $1.26 \mathrm{bc}$ \\
Yeast at 1 g/pot (B) & $11.96 \mathrm{~cd}$ & $13.24 \mathrm{de}$ & $1.10 \mathrm{c}$ & $1.26 \mathrm{c}$ & $0.13 \mathrm{bc}$ & $0.19 \mathrm{bc}$ & $1.13 \mathrm{bc}$ & $1.21 \mathrm{bc}$ \\
Yeast at 3 g/pot (C) & $12.17 \mathrm{c}$ & $14.50 \mathrm{~d}$ & $1.16 \mathrm{c}$ & $1.30 \mathrm{c}$ & $0.16 \mathrm{~b}$ & $0.23 \mathrm{~b}$ & $1.20 \mathrm{~b}$ & $1.30 \mathrm{~b}$ \\
Yeast at 5 g/pot (D) & $13.73 \mathrm{~b}$ & $16.22 \mathrm{bc}$ & $1.29 \mathrm{bc}$ & $1.39 \mathrm{bc}$ & $0.22 \mathrm{~b}$ & $0.26 \mathrm{~b}$ & $1.31 \mathrm{ab}$ & $1.40 \mathrm{~b}$ \\
A + B & $14.00 \mathrm{~b}$ & $16.58 \mathrm{bc}$ & $1.39 \mathrm{~b}$ & $1.56 \mathrm{~b}$ & $0.25 \mathrm{ab}$ & $0.34 \mathrm{ab}$ & $1.29 \mathrm{~b}$ & $1.35 \mathrm{~b}$ \\
A + C & $15.36 \mathrm{a}$ & $18.33 \mathrm{a}$ & $1.78 \mathrm{a}$ & $1.95 \mathrm{a}$ & $0.31 \mathrm{a}$ & $0.42 \mathrm{a}$ & $1.57 \mathrm{a}$ & $1.70 \mathrm{a}$ \\
A+ D & $14.51 \mathrm{ab}$ & $17.10 \mathrm{~b}$ & $1.56 \mathrm{ab}$ & $1.76 \mathrm{ab}$ & $0.27 \mathrm{ab}$ & $0.36 \mathrm{ab}$ & $1.40 \mathrm{ab}$ & $1.46 \mathrm{ab}$ \\
\hline
\end{tabular}

- Means within a column having the same letters are not significantly different according to Duncan's Multiple Range Test (DMRT) at 5\% level.

connecting between active dry yeast at $3 \mathrm{~g} / 1$ and NPK mixture at $2 \mathrm{~g} /$ pot, as such combination registered the highest content over control and other treatments in the two seasons. This may be ascribed to the synergistic effect of both active yeast and NPK on supplying the plants luxuriously with several nutrients and vital components that accelerate biosynthesis rate and lead finally to accumulation of more constituents in plant tissues. Several reports are in line with the aforetasted results, such as those of Ahmed (2002) on Lucaena leucocephala, AbdelWahed (2007) on Brassaia arboricola, ElSayed et al. (2010) on Spathiphyllum wallisii and Abdo et al. (2012) on soybean.

Accordingly, it is advised to fertilize Peperomia obtusifolia cv. Variegata plants cultivated in 14-cm-diameter plastic pots with active dry yeast at $3 \mathrm{~g} / \mathrm{l}$ (as a foliar spray) plus NPK mixture $(2: 2: 1)$ at $2 \mathrm{~g} /$ pot (as a soil drench, 5 times with one month interval to obtain the best growth and high quality.

\section{REFERENCES}

Abdel-Fattah, Gehan, H.; Abdel-Moniem, Azza M. and El-Shamy, M.A.E, (2009). Response of Australian umbrella tree (Brassaai) transplants to some fertilization, salicylic acid and dry yeast treatments. Ann. Agri. Sci., Moshtohor, 47(2):275-283.

Abdel-Wahed, S.M.K. (2007). Response of Brassaia arboricola Endle. plants to active dry yeast and some trace elements (Zinc-Manganese). Egyptian J. Appl. Sci., 22(3):142-160.

Abdel-Wahed, Safwat, M.K.; Labib, Naglaa, Y. and Rezk-Alla, B.B. (2006). Effect of active dry yeast and chemical fertilization on vegetative growth and the main constituents of Euonymus japonicus thunb. Plant. Fayoum J. Agric. Res. \& Dev., 20(1):136-147.

Abdo, F. A.; Nassar, D.M.A.; Gomaa, E.F. and Nassar, R.M.A. (2012). Minimizing the harmful effects of cadmium on vegetative growth, leaf anatomy, yield and physiological characteristics of soybean plant by foliar spray with active yeast extract or garlic cloves extract. Res. J. of Agric. \& Biol. Sci., 8(1):24-35.

Abou El-Yazied, A. and Mahdy, M.A. (2012). Effect of boron and yeast extract foliar application on growth pod setting and both green pod and seed yield of broad bean (Vicia faba L.). J. Amer. Sci., 8(4):517-533.

Ahmed, A.A. (2002). Study the effect of addition methods and concentrations of active dry yeast on the growth and chemical composition of Lucaena leucocephala. Minia $1^{\text {st }}$ Conf. Agric. Environ. Sci., 25-28 March, Fac. Agric., Minia Univ., Egypt: 33-43.

Ali, A.F. (2001). Response of Calendula officinalis L. plants to some rock phosphate source and yeast. The $5^{\text {th }}$ 
Arabian Hort. Conf., 24-28 March, Ismailia, Fac. Agric., Egypt: 30-42.

Bailey, L.H. (1976). Hortus Third, Macmillan Publishing Co., Inc., 866 Third Avenue, New York, N. Y. 10022. Collier Macmillan Canda, Inc., Printed in USA, pp. 1290.

Cottenie, A.; Verloo, M.; Kiekan, L.; Velghe, G. and Comerlynck, R. (1982). Chemical Analysis of Plants and Soils. Laboratory of Analytical and Agrochemistry. State Univ., Ghent-Belgium, p. 45.

Desouky, M.T. (2004). Improving efficacy of different NPK fertilizer levels on Strelitizia reginae. Ait plant by using active dry yeast. Ann. Agric., Sci., Moshtohor, 42(1):239-250.

Dubois, M.; Smith, F.; Illes, K.A.; Hamilton, J.K. and Rebers, P.A. (1956). Colorimetric mehod for determination of sugars and related substances. Ann. Chem., 28(3):350-356.

Duncan, D.B. (1955). Multiple range and multiple F. Tests. Biometrics,11:1- 24.

El-Sayed, Boshra, A.; Abdel-Moniem, Azza M. and Shahin, S.M. (2010). Improving efficiency of NPK fertilizer for Spthiphyllum plant by using active dry yeast at various levels. J. Biol. Chem. \& Environ. Sci., 5(4):1-12.

El-Sayed, Boshra, A.; Shahin, S.M. and Eliwa, Naglaa, Y.L. (2007). How far nitrobien and gibberellic acid can improve growth and chemical composition of Peperomia obtusifolia cv. Vaiegata (L.) A. Dietr transplants?. J. Biol. Chem. \& Environ. Sci., 2(4):167179.
Huxley, A.; Griffiths, M. and Levy, M. (1992). The New Royal Hort. Society Dictionary of Gardening. The Stockton Press, New York, 257 Park Avenue South, N. Y. 10010, USA, Vol. 3, 790 pp.

Jackson, M.H. (1973). Soil Chemical Analysis. Prentice-Hall of India Private Limited M-97, New Delhi, India, 498 pp.

Mead, R.; Curnow, R.N. and Harted, A.M. (1993). Statistical Methods in Agriculture and Experimental Biology. $2^{\text {nd }}$ Ed., Chapman \& Hall Ltd., London, 335 pp.

Nassar, R.M.A.; Ahmed, Y.M. and Nassar, D.M.A. (2011). Effect of foliar spray with active yeast extract on morphological, anatomical and yield characteristics of Phaseolus vulgaris L. Australian J. of basic and Appli. Sci., 5 (5):1071-1079.

Pregl, F. (1945). Quantitative Organic microanalysis $4^{\text {th }}$ Ed. J \& A., churvhill, Ltd. London, p. 203-209.

Samet, A.E.; Piri, K.; Kayhanfar, M. and Hasanloo, T. (2012). Influence of hasmonic acids, yeast extract and salicylic acid on growth and accumulation of hyosciamine and Scopolamine in hairy root cultures of Atropa belladonna L. Inter J. Agric.; Res. And Rev., 2(4):403-409.

Saric, M.; Kastrori, R.; Curic, R.; Cupina T. and Geric, I. (1967). Chlorophyll Determination. Univ U Noven Sadu Parktikum is Fiziologize Biljaka, Beogard, Haucna, Anjiga, p. 215.

SAS Institute Program (1994). SAS/STAT User`s Guides Statistics. Vers. 6.04, $4^{\text {th }}$ Ed., SAS. Institute Inc. Cary, N.C., USA. 


\section{Boshra A. El-Sayed et al.}

\section{استجابة نبات البيروميا (صنف فاريجاتا) لبعض معاملات التسميد}

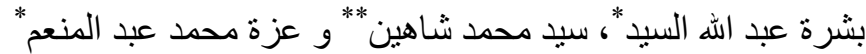

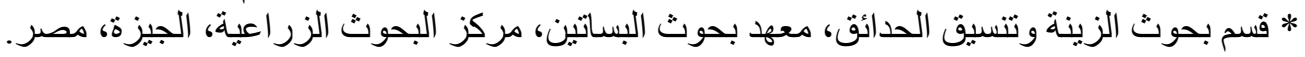

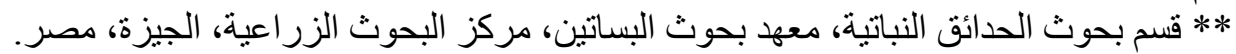

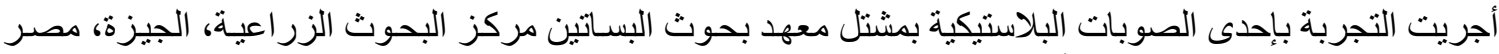

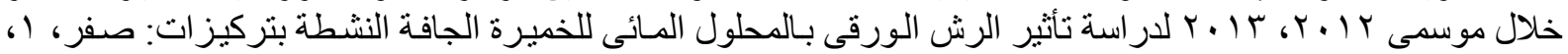

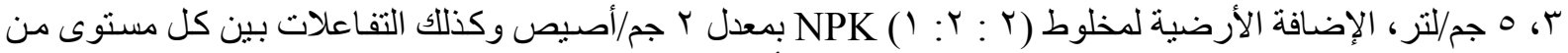

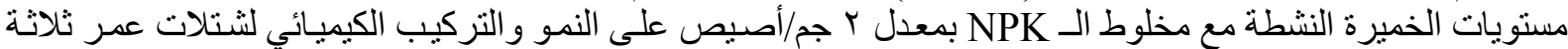

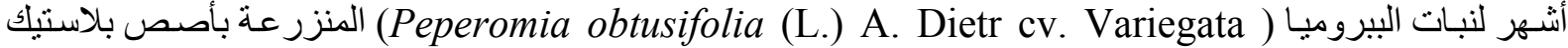

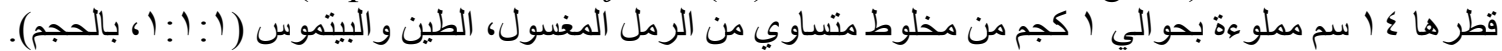

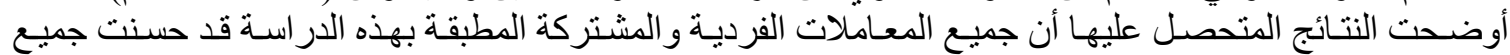

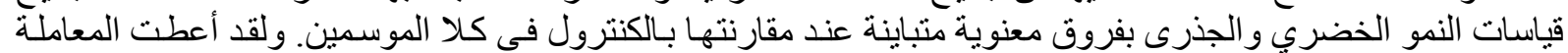

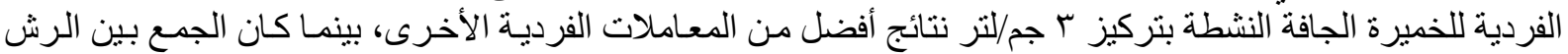

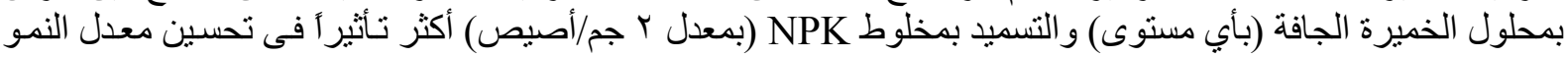

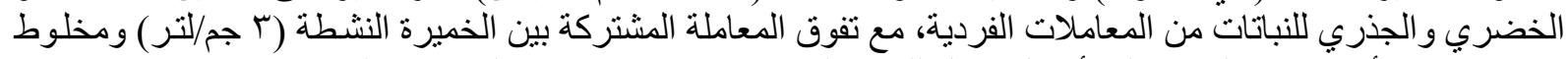
NPK

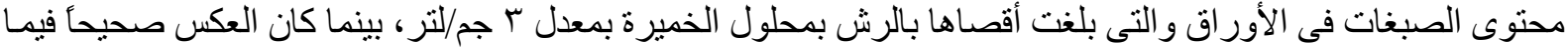

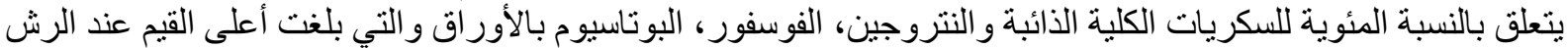

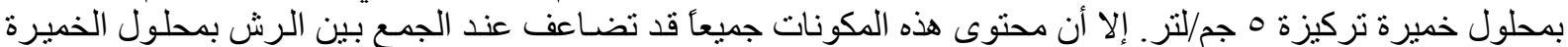

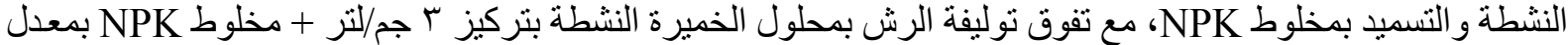

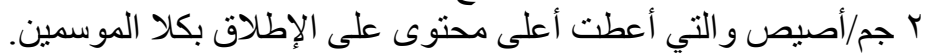

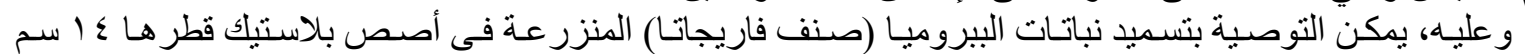

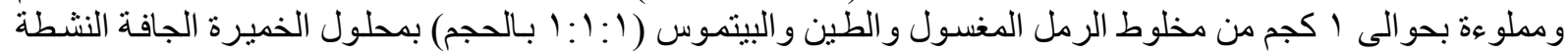

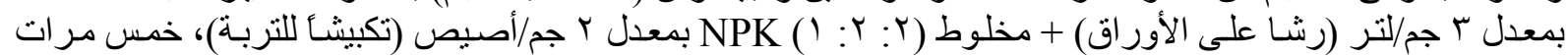

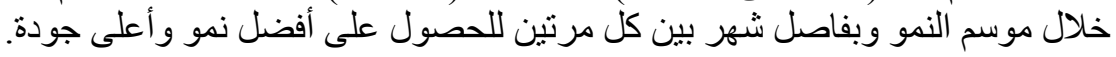

